\title{
Homogeneous time-resolved fluorescence-based assay to monitor extracellular signal-regulated kinase signaling in a high-throughput format
}

\author{
Mohammed Akli Ayoub ${ }^{1}$ *, Julien Trebaux ${ }^{2}$, Julie Vallaghe ${ }^{2}$, Fabienne Charrier-Savournin ${ }^{2}$, \\ Khaled Al-Hosaini ${ }^{3}$, Arturo Gonzalez Moya ${ }^{2}$, Jean-Philippe Pin ${ }^{3}$, Kevin D. G. Pfleger ${ }^{1}$ and Eric Trinquet ${ }^{2 *}$ \\ 'Molecular Endocrinology and Pharmacology, Harry Perkins Institute of Medical Research and Centre for Medical Research, The University of Western Australia, \\ Nedlands, WA, Australia \\ ${ }^{2}$ Cisbio Bioassays, Codolet, France \\ ${ }^{3}$ Department of Molecular Pharmacology, CNRS UMR5203, INSERM U661, Institute of Functional Genomics, Universities Montpellier 1 \& 2, Montpellier, France
}

\section{Edited by:}

Tarik Issad, University Paris

Descartes, France

Reviewed by:

Guillermo Romero, University of

Pittsburgh, USA

Julie Dam, INSERM, France

\section{*Correspondence:}

Mohammed Akli Ayoub, BIOS group, INRA, UMR85, Unité physiologie de la reproduction et des comportements, 37380 Nouzilly, France

e-mail: mohammed.ayoub@tours.

inra.fr;

Eric Trinquet, Cisbio Bioassays, Parc Technologique Marcel Boiteux, BP84175, Codolet 30200, France e-mail: etrinquet@cisbio.com
The extracellular signal-regulated kinases (ERKs) are key components of multiple important cell signaling pathways regulating diverse biological responses. This signaling is characterized by phosphorylation cascades leading to ERK1/2 activation and promoted by various cell surface receptors including G protein-coupled receptors (GPCRs) and receptor tyrosine kinases (RTKs). We report the development of a new cell-based Phospho-ERK1/2 assay (designated Phospho-ERK), which is a sandwich proximity-based assay using the homogeneous time-resolved fluorescence technology. We have validated the assay on endogenously expressed ERK $1 / 2$ activated by the epidermal growth factor as a prototypical RTK, as well as various GPCRs belonging to different classes and coupling to different heterotrimeric $G$ proteins. The assay was successfully miniaturized in 384-well plates using various cell lines endogenously, transiently, or stably expressing the different receptors. The validation was performed for agonists, antagonists, and inhibitors in dose-response as well as kinetic analysis, and the signaling and pharmacological properties of the different receptors were reproduced. Furthermore, the determination of a $Z^{\prime}$-factor value of 0.7 indicates the potential of the Phospho-ERK assay for high-throughput screening of compounds that may modulate ERK $1 / 2$ signaling. Finally, our study is of great interest in the current context of investigating ERK $1 / 2$ signaling with respect to the emerging concepts of biased ligands, G protein-dependent/independent ERK1/2 activation, and functional transactivation between GPCRs and RTKs, illustrating the importance of considering the ERK1/2 pathway in cell signaling

Keywords: HTRF ${ }^{\oplus}$, ERK1/2, GPCR, RTK, EGFR

\section{INTRODUCTION}

The activation of mitogen-activated protein kinases (MAPKs) constitutes one of the major intracellular signaling pathways that couples signals from cell surface receptors, such as receptor tyrosine kinases (RTKs) and G protein-coupled receptors (GPCRs), to gene expression regulation and other intracellular events (16). Indeed, following stimulation, these receptors promote a

Abbreviations: AngII, angiotensin II; AT1R, angiotensin II type 1 receptor; AVP, arginine-vasopressin peptide; cAMP, cyclic adenosine mono-phosphate; CB1, cannabinoid receptor 1; CHO, Chinese hamster ovary; DAMGO, Tyr-Ala-Gly$N$-methyl-Phe-Gly-ol; EGF, epidermal growth factor; EGFR, epidermal growth factor receptor; ELISA, enzyme-linked immunosorbent assay; ERK, the extracellular signal-regulated kinase; FRET, fluorescence resonance energy transfer; GPCR, G protein-coupled receptors; HEK293, human embryonic kidney 293 cells; HTRF, homogenous time-resolved fluorescence; HTS, high-throughput screening; MCP1 , monocyte chemoattractant protein $1 ;$ MIP $1 \beta$, macrophage inflammatory protein $1 \beta$; MOP3R, $\mu$-opioid receptor 3; NMU2R, neuromedin receptor 2; PAR1, proteaseactivated receptor 1; PGE2, prostaglandin E2; PTX, pertussis toxin; RTK, receptor tyrosine kinase; S1P5, sphingosine-1-phosphate receptor 5; SDF1 $\alpha$, stromal cellderived factor $1 \alpha$; V2R, vasopressin V2 receptor VIP, vasoactive intestinal peptide; VPAC1, Vasoactive intestinal polypeptide receptor 1. sequential protein kinase cascade (involving MAP4Ks, MAP3Ks, and MAP2Ks) leading to the activation of ERKs (mostly ERK1/2, also called p44/p42 MAPK) by MAP2K members (also called MEKs) $(5,7,8)$. In this cascade, MEK1/2 is phosphorylated and activated by the Ras/Raf pathway and other MAP kinase kinase kinases (MAP3Ks) through serine phosphorylation at the typical Ser-Xaa-Ala-Xaa-Ser/Thr motif in their activation loop (serine 218 and 222 for MEK1) $(8,9)$. Then, the activation of the ERK1/2 occurs by phosphorylation of both threonine and tyrosine residues in the Thr-Glu-Tyr motif in their activation loop (Threonine 202/Tyrosine 204 for ERK1 and Threonine 185 and Tyrosine 187 for ERK2) $(8,10)$. The activation of the ERK1/2 pathway leads to the modulation of diverse downstream transcription factors (NF$\kappa \mathrm{B}, \mathrm{CREB}, \mathrm{AP}-1$, and $\mathrm{c}-\mathrm{Myc})$ controlling the expression of the key genes involved in the control of cell division, differentiation and apoptosis (11).

Therefore, the development of a robust, highly sensitive and specific assay to investigate the activation of ERK1/2 is of great interest for both academic and industry researchers and laboratories. Indeed, for many years the most useful and widely 
utilized method to investigate the ERK1/2 pathway has been based on SDS-PAGE followed by Western blot using anti-PhosphoERK1/2 antibodies. Even though successful and reproducible, this method has the considerable limitation of being time-consuming, since protein extraction, electrophoresis, protein transfer, and then overnight antibody incubation are required. In addition, western blot analysis is not always quantitative, impairing applicability to high-throughput screening (HTS), and drug profiling programs. Alternative recent techniques have been proposed and developed (12), such as the enzyme-linked immunosorbent assay (ELISA), the Meso-Scale Assay electrochemiluminescence-based method (13), the LICOR infrared fluorescence-based method (14), and TGR BioSciences' SureFire ${ }^{\circledR}$ assay that uses the AlphaScreen ${ }^{\mathrm{TM}}$ technology (PerkinElmer) $(15,16)$. These have been reviewed collectively (17). Recently, a BRET-based ERK biosensor has also been developed to temporally and spatially assess ERK activation (18).

Here, we describe a homogeneous time-resolved fluorescence (HTRF $\left.{ }^{\circledR}\right)$ cell-based assay compatible with HTS to investigate the intracellular ERK1/2 signaling pathway. $\mathrm{HTRF}^{\circledR}$ combines fluorescence resonance energy transfer (FRET) technology with timeresolved (TR) measurement $(19,20)$. Since its development, this technology has been applied to many antibody-based assays (19), including second messengers (cAMP and IP-One) (21-24), kinases (25), oligomerization of GPCRs $(26,27)$ and RTKs (28), G protein activation and $\beta$-arrestin recruitment (29), ligand-receptor binding (30, 31), cytokines and biomarkers (32), and proteinDNA/RNA interactions (33), and recently ERK1/2 with the calcium-sensing receptor (22). The Phospho-ERK assay has been validated using the two major cell surface receptor families, RTKs and GPCRs, where both agonist-induced ERK1/2 phosphorylation and inhibition by receptor-selective inhibitors/antagonists as well as the comparison with the classical western blot technique were investigated in cell lines endogenously, transiently, or stably expressing the different receptors.

\section{MATERIALS AND METHODS}

\section{CELL LINES, PLASMIDS, AND REAGENTS}

We used the $\mathrm{HTRF}^{\circledR}$ Phospho-ERK kit (Catalog number 64ERKPEG) recently launched by Cisbio Bioassays. Chinese hamster ovary $(\mathrm{CHO})$ cells stably expressing the different GPCRs were generated by Euroscreen (Gosselies, Belgium), except the CHOmuscarinic M1 receptor (M1) cell line that was kindly provided by Dr. Denis Servent (CEA-DSV, Saclay, France). NIH-3T3, A431, HEK293, HeLa, and SKOV3 cell lines were from American Type Culture Collection (Manassas, VA, USA). HEK293FT cells were from Life Technologies (Burwood, VIC, Australia). All the plasmids coding for the GPCRs used in Figure 4 were generated and/or purchased by Kevin D. G. Pfleger's laboratory from Missouri S\&T cDNA Resource Center ${ }^{1}$ and AT1R and NMU2R plasmids were gifts from Prof. Walter Thomas (University of Queensland, Australia) and Dr. Gary B. Willars (University of Leicester, UK), respectively. All the agonists (EGF, MCP-1, MIP1 $\beta$, SDF1 $\alpha$, DAMGO, Endorphin-2, Norepinephrine, Isoproterenol, ACEA, PGE2, ITAC, FTY720, VIP, arginine-vasopressin (AVP), carbachol, Ang II, and

\footnotetext{
${ }^{1}$ http://www.cdna.org
}

human Neuromedin U-25), the antagonist CTOP and Pertussis toxin were from Sigma. The anti-Phospho-ERK1/2 antibody used for western blot was purchased from Cell Signaling Technology.

\section{CELL CULTURE AND TRANSIENT TRANSFECTIONS}

Cells were maintained at $37^{\circ} \mathrm{C}, 5 \% \mathrm{CO}_{2}$ in Complete Media (Dulbecco's modified Eagle's medium containing $0.3 \mathrm{mg} / \mathrm{ml}$ glutamine, $100 \mathrm{IU} / \mathrm{ml}$ penicillin, and $100 \mathrm{mg} / \mathrm{ml}$ streptomycin; Gibco) supplemented with $10 \%$ fetal calf serum (FCS). Transient transfections were carried out using Lipofectamine 2000 (Invitrogen) or GeneJuice (Novagen) according to manufacturer's instructions. Cells were harvested with $0.05 \%$ Trypsin-EDTA (Gibco).

\section{ONE-PLATE PROTOCOL OF THE PHOSPHO-ERK ASSAY}

Cells endogenously, transiently, or stably expressing the different receptors were cultured overnight in a 384 -well white plate $(5000$ cells/well) using $8 \mu \mathrm{l}$ of medium/well. Then $4 \mu \mathrm{l} /$ well of the $1 \times$ stimulation buffer, containing or not the different agonists at the different concentrations as indicated, were added to the cells. After incubation at room temperature, cells were lysed by adding to the stimulation mix $4 \mu \mathrm{l} /$ well of the supplemented lysis buffer, followed by incubation for 30-45 $\mathrm{min}$ at room temperature with shaking. Then $2 \mu \mathrm{l}$ of anti-ERK1/2-Europium/Terbium Cryptate and $2 \mu$ l of anti-Phospho-ERK1/2-d2 antibody solutions prepared in the detection buffer were added. The plate was then incubated for at least $2 \mathrm{~h}$ at room temperature before reading the fluorescence emission at 620 and $665 \mathrm{~nm}$ using either a Tecan Infinite 500 (Tecan Group Ltd.) or RUBYstar or PHERAstar FS plate reader (BMG Labtech).

\section{TWO-PLATE PROTOCOL OF THE PHOSPHO-ERK ASSAY}

Cells endogenously, transiently, or stably expressing the different receptors were cultured in a 96-well cell culture plate (5$10 \times 10^{4}$ cells/well, which corresponds roughly to $25 \mu \mathrm{g}$ of proteins). Twenty-four hours after cell transfection, cells were starved overnight in DMEM-serum free medium and then incubated in a total volume of $50 \mu \mathrm{l} /$ well of the $1 \times$ stimulation buffer, containing or not the different agonists at the different concentrations as indicated. Cells were incubated at room temperature before the stimulation mix was removed and cells were then lysed in $50 \mu \mathrm{l} /$ well of the supplemented lysis buffer for 30-45 min at room temperature with shaking. Then $16 \mu \mathrm{l}$ of each lysate was transferred into a 384-well small volume white plate and made up to the final volume of $20 \mu \mathrm{l} /$ well with $2 \mu \mathrm{l}$ of anti-ERK1/2-Europium/Terbium Cryptate and $2 \mu \mathrm{l}$ of anti-Phospho-ERK1/2-d2 antibody solutions prepared in the detection buffer. The plate was then incubated for $2 \mathrm{~h}$ at room temperature before reading the fluorescence emission at 620 and $665 \mathrm{~nm}$ using a Tecan Infinite 500 (Tecan Group Ltd.), RUBYstar, or PHERAstar FS plate reader (BMG Labtech), or an EnVision 2102 plate reader (PerkinElmer).

\section{COMPARISON BETWEEN HTRF ${ }^{\circledR}$-BASED PHOSPHO-ERK ASSAY AND WESTERN BLOT}

A431 cells were seeded in $175 \mathrm{~cm}^{2}$ flasks. After $48 \mathrm{~h}$ incubation, cells were washed with $10 \mathrm{ml}$ PBS and then stimulated for $5 \mathrm{~min}$ with $5 \mathrm{ml}$ of EGF diluted at $100 \mathrm{nM}$ in serum free medium. After stimulation, cells were washed with $10 \mathrm{ml}$ PBS and then lysed with 


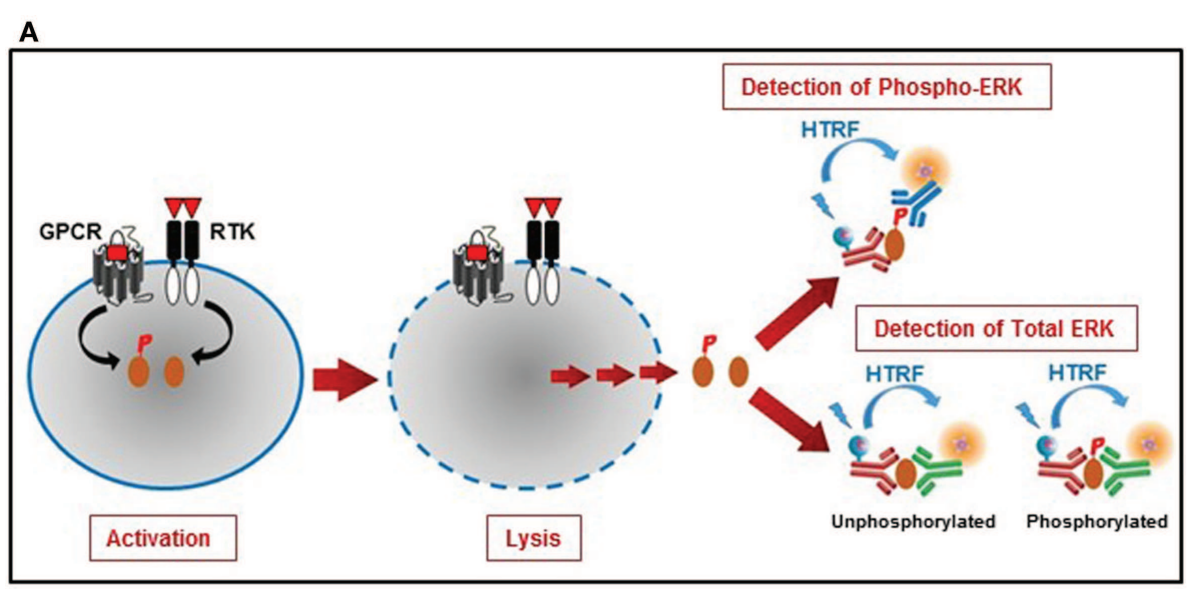

\section{B One-plate assay protocol}

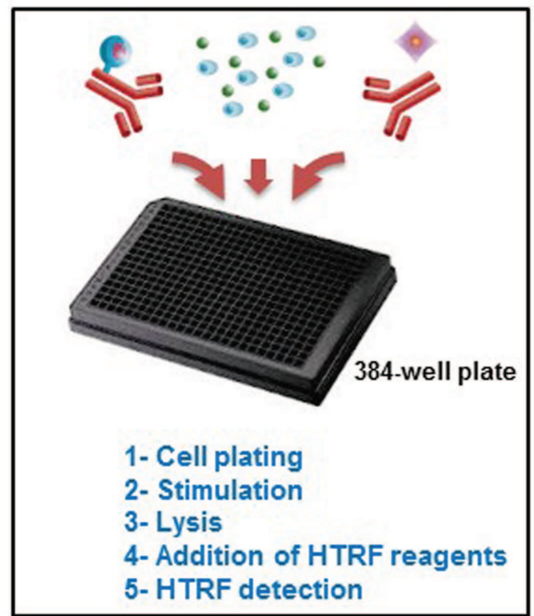

\section{Two-plate assay protocol}

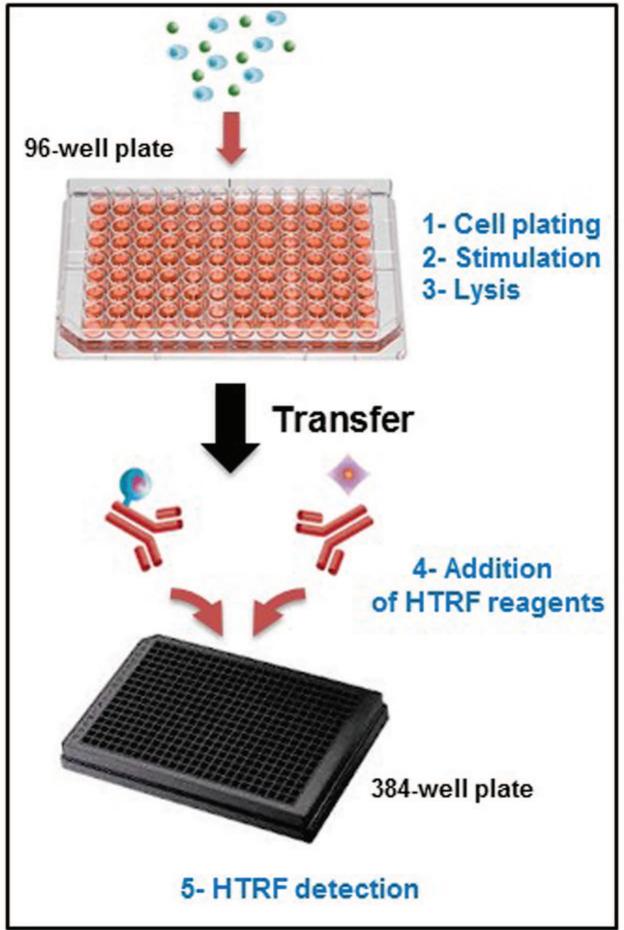

small volume plate, and (C) the two-plate protocol in which the stimulation and lysis steps are performed in the total volume of $50 \mu \mathrm{l}$ using the initial 96-well plate containing the cells, then the cell lysate is transferred into a 384-well small volume plate for HTRF detection after addition of HTRF conjugated-antibodies as described in Section "Materials and Methods" (Adapted from the CisBio Bioassays website ${ }^{2}$ with permission).
$3 \mathrm{ml}$ of $1 \times$ HTRF complete lysis buffer for $30 \mathrm{~min}$ at room temperature. Following centrifugation, the supernatant was collected, and serial dilutions of lysates (1:2) were performed in $1 \times$ HTRF complete lysis buffer. For the HTRF assay, $16 \mu \mathrm{l}$ of each diluted sample was dispensed in a white 384-well small volume plate and detection was performed as described in the following section. For western blot analysis, $16 \mu \mathrm{l}$ of each diluted sample was denatured with
Laemmeli buffer and proteins were separated on a polyacrylamide gel (NuPAGE Novex 4-12\% Bis-Tris Gel). After electrotransfer, PVDF membranes were blocked in 5\% non-fat dry milk in TrisBuffered Saline $-0.1 \%$ Tween-20 (TBS-T). After washing steps,

${ }^{2}$ http://www.htrf.com 

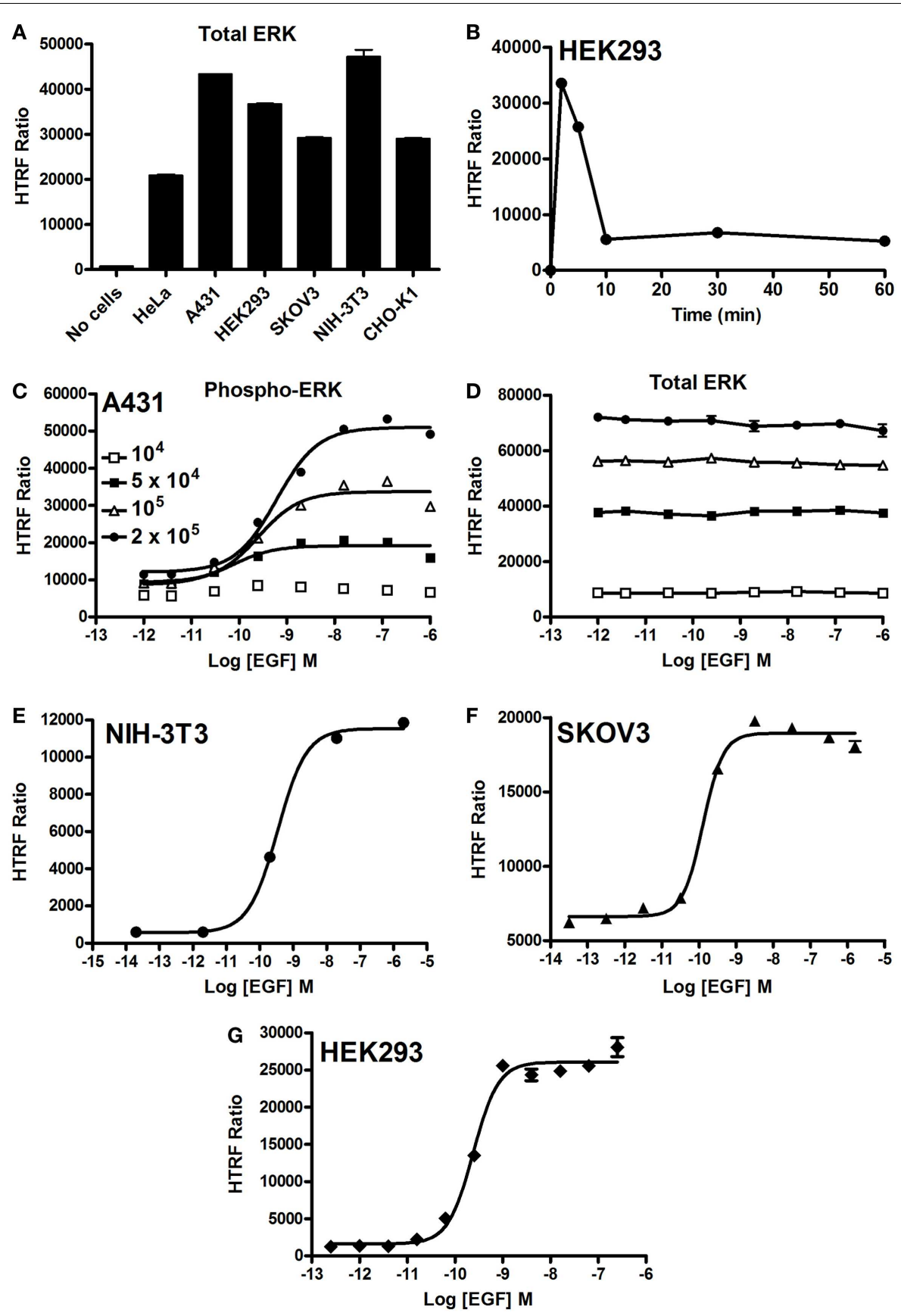

FIGURE 2 | EGF-promoted Phospho-ERK1/2 activation detected by the Phospho-ERK assay. (A) Total ERK levels quantified in various cell lines. (B) Kinetics of EGF-induced ERK1/2 activation in HEK293 cells endogenously expressing EGFR upon their stimulation with $100 \mathrm{nM}$ of EGF. (C,D) The effect of cell density on the phosphorylation of ERK1/2 (C) versus total ERK1/2 (D) upon stimulation with increasing concentrations of
EGF as indicated. EGF-induced Phospho-ERK1/2 in various cell lines endogenously expressing EGFR: NIH-3T3 (E), SKOV3 (F), and HEK293 (G) cells $\left(10^{5}\right.$ cells/well) stimulated for 5 min with increasing concentrations of EGF before HTRF measurements were performed using the one-plate protocol. The data are mean \pm SEM of three independent experiments performed in duplicate. membranes were incubated with anti-Phospho-ERK1/2 or antitotal ERK antibodies, diluted at $1 \mu \mathrm{g} / \mathrm{ml}$ in TBS-T with $5 \%$ Bovine Serum Albumin (BSA). After overnight incubation at $4^{\circ} \mathrm{C}$ under gentle agitation, membranes were washed three times with TBS-T, and incubated with HRP-conjugated secondary antibody. After
$1 \mathrm{~h}$ incubation at room temperature, membranes were washed four times with TBS-T and incubated with SuperSignal West Femto Chemiluminescent Substrate for $5 \mathrm{~min}$ at room temperature. Chemiluminescent signal was acquired on a G:BOX imaging system (Syngene, Cambridge, UK). 

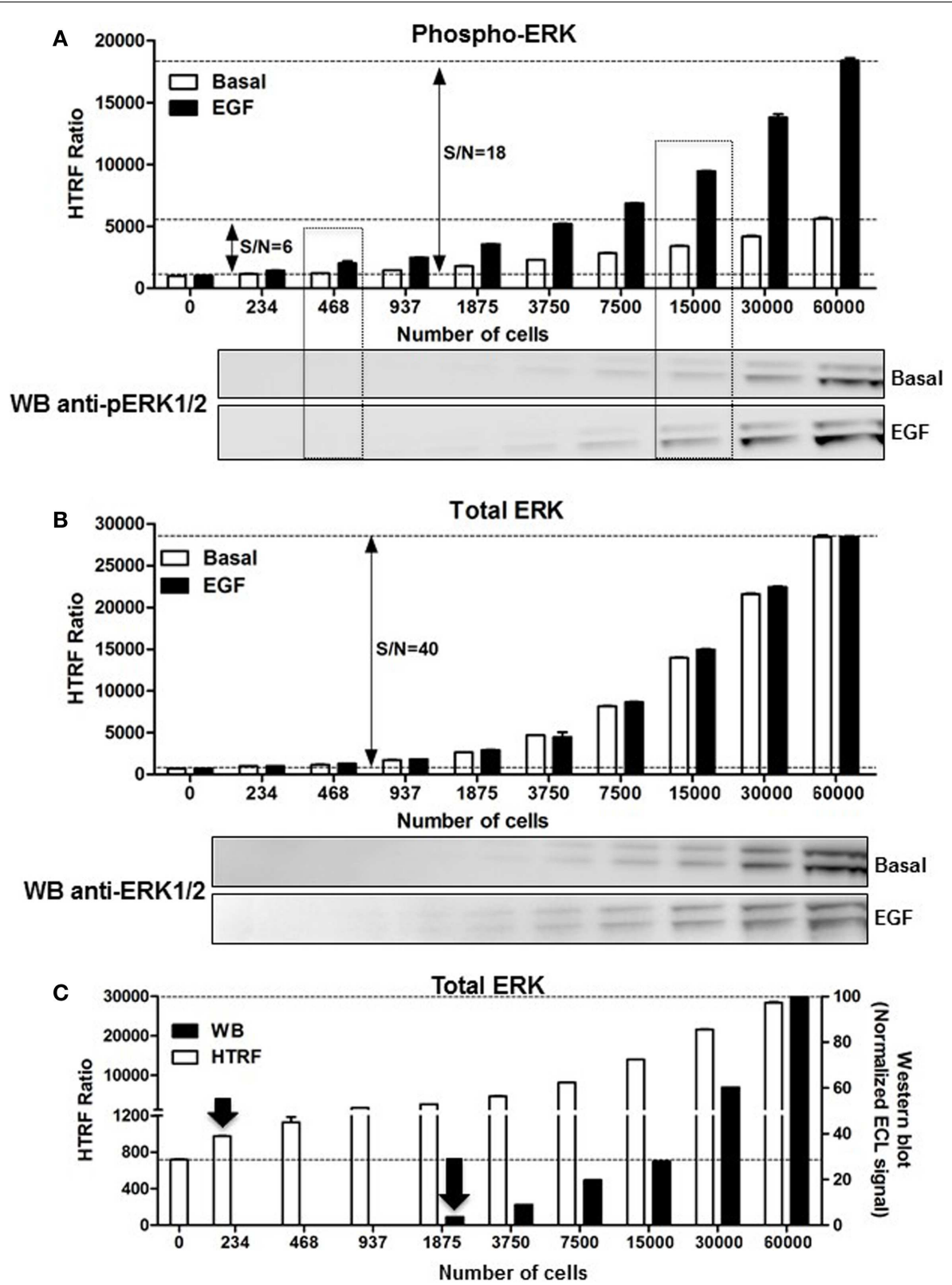

FIGURE 3 | Comparison of the Phospho-ERK and western blot assays and effect of cell density. A431 cells were used for the detection of the phosphorylation of ERK $1 / 2$ upon cell stimulation with $100 \mathrm{nM}$ of EGF for 5 min (A) as well as the corresponding total ERK levels using the one-plate protocol (B). S/N represents the signal-to-noise ratio through the different cell densities. For this, serial dilutions of whole cells or cell lysate were dispensed as indicated and analyzed side-by-side using the HTRF assay [top of $(\mathbf{A}, \mathbf{B})$ ] and western blot [bottom of $(\mathbf{A}, \mathbf{B})$ ] as described in Section "Materials and Methods." (C) The detection limit of the total ERK levels using the two methods was represented by plotting the total HTRF signals (HTRF) with the enhanced chemiluminescence (ECL) signal obtained by densitometry from the western blot (WB) normalized to the signal obtained with 60,000 cells/well as $100 \%$. The data are mean \pm SEM of three independent experiments performed in duplicate.

\section{DATA PRESENTATION AND ANALYSIS}

Data are presented as HTRF ratios, which are calculated as the ratio between the emission at $665 \mathrm{~nm}$ and the emission at $620 \mathrm{~nm}$ $(\times 10,000)$. The sigmoidal curves were fitted to the dose-response data using non-linear regression [Log (ligand) versus HTRF ratio] by Prism 5 graphing software (GraphPad, La Jolla, CA, USA).

\section{RESULTS AND DISCUSSION}

In this study, we have reported validation of the HTRF ${ }^{\circledR}$-based Phospho-ERK assay to investigate the intracellular ERK1/2 signaling pathway, compatible with HTS in 96-well and 384-well plate formats. Epidermal growth factor receptor (EGFR) as a prototypical RTK and various GPCRs were tested in endogenous, stable, 

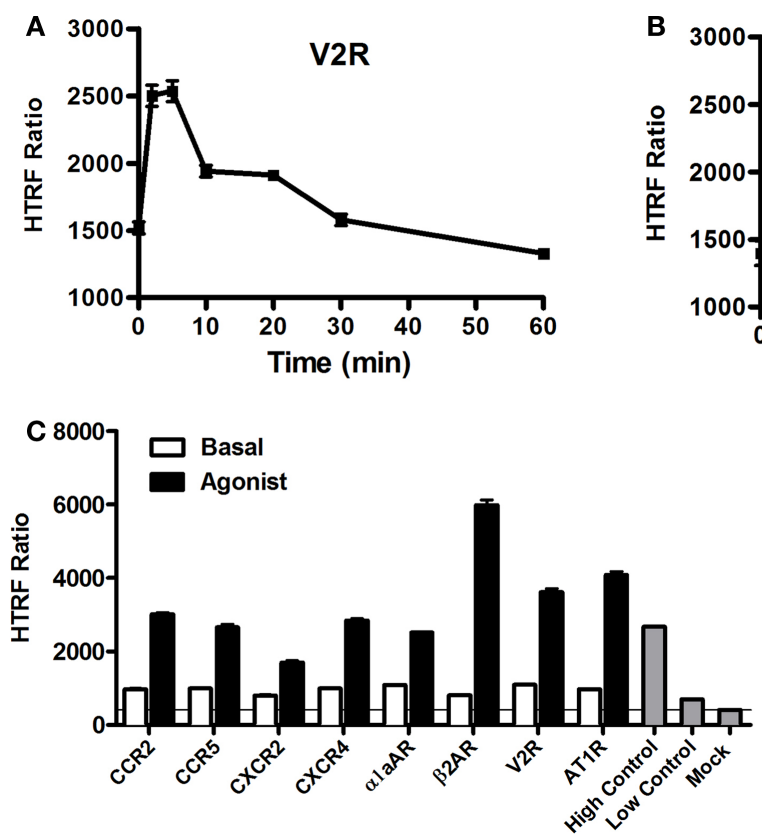

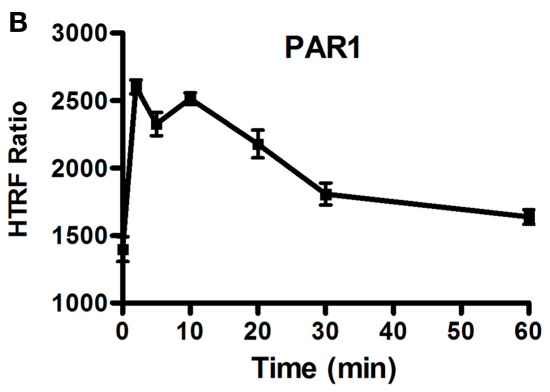

D

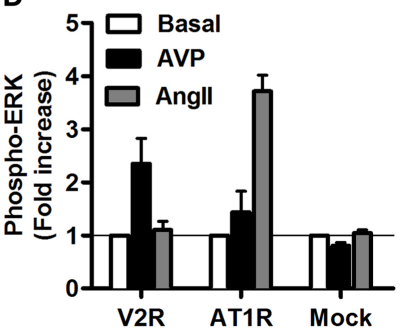

FIGURE 4 | GPCR-mediated Phospho-ERK1/2 monitored by the Phospho-ERK assay. HEK293 cells ( $10^{5}$ cells/well) transiently expressing the different GPCRs indicated were used for the Phospho-ERK1/2 assay under basal conditions or upon cell stimulation at different time points (A,B) or $5 \mathrm{~min}$ (C,D) with $100 \mathrm{nM}$ of the GPCR-specific agonists: AVP for V2R, thrombin (1 U/ml) for PAR1, MCP-1 for CCR2, MIP1 $\beta$ for CCR5, IL-8 for CXCR2, SDF1 $\alpha$ for CXCR4, Norepinephrine for $\alpha 1 \mathrm{aAR}$, Isoproterenol for $\beta 2 A R$, and Angll for AT1R. Phospho-ERK1/2 detection was performed using the two-plate protocol, which included the additional measurement of high and low controls instead of the cell lysate. The data are mean \pm SEM of three independent experiments performed in duplicate (A-C) or represented as fold increase in Phospho-ERK1/2 over basal and the resultant values are mean \pm SEM of three independent experiments performed in triplicate (D). and transient expression models. The assay has been validated by studying multiple aspects including kinetics, dose-dependent effects of agonists and inhibitors, phosphorylated versus total ERK1/2, and the implication of heterotrimeric $G$ proteins.

\section{PRINCIPLE OF HTRF ${ }^{\circledR}$-BASED PHOSPHO-ERK1/2 ASSAY (PHOSPHO-ERK ASSAY)}

Phospho-ERK is an in vitro assay developed to assess the phosphorylation of ERK1/2, a fingerprint of the MAP kinase signaling pathway promoted by a variety of cell surface receptor families such as GPCRs and RTKs. The assay is a sandwich immunoassay comprising three straightforward steps: (i) cell activation, (ii) cell lysis, and (iii) detection of HTRF signals (Figure 1A). The detection of HTRF signals is based on the incubation of the cell lysate with an anti-ERK1/2 antibody labeled with Europium cryptate that recognizes all ERK1/2 proteins, combined with either an anti-ERK1/2 antibody (for the unphosphorylated forms) or anti-Phospho-ERK1/2 antibody (for the phosphorylated forms) labeled with d2 (Figure 1A). The proximity generated by the simultaneous binding of the two antibodies leads to an efficient FRET between the europium cryptate and the sensitized acceptor, $\mathrm{d} 2$. The resulting acceptor emission at $665 \mathrm{~nm}$ is then used as the assay readout. We have validated the assay using two different protocols, one-plate (Figure 1B), and two-plate (Figure 1C) protocols, as described in Section "Materials and Methods."

\section{USE OF THE PHOSPHO-ERK ASSAY TO MONITOR EGFR-MEDIATED ERK1/2 ACTIVATION}

First, we quantified the total ERK1/2 levels in various cell lines using our HTRF-based assay and as shown in Figure 2A. Positive and specific HTRF signals reflecting the total ERK1/2 were measured and the signal varied with the cell line used. Then, we assessed the kinetics of ERK1/2 phosphorylation mediated by EGFR endogenously expressed in HEK293 cells. As shown in Figure 2B, stimulation with $100 \mathrm{nM}$ EGF showed a maximal level of ERK1/2 phosphorylation at 2-5 min of stimulation, which had largely disappeared after $10 \mathrm{~min}$. The transient EGF-induced ERK1/2 activation is consistent with many previous studies using different cell lines (34-36). Consequently, all the data on EGFR presented below have been generated at $5 \mathrm{~min}$ of stimulation with EGF. Next, we examined the effect of cell density on EGFinduced HTRF signals in the epidermal carcinoma-derived cell line A431 known as a good cell model for the study of endogenous EGFR activation and signaling. As shown in Figure 2C, the dose-response effect of EGF proportionally increased with the total number of cells per well. Such increase was consistent with the HTRF signals reflecting the total ERK1/2 expressed in the cells (Figure 2D). However, the HTRF signal resulting from total ERK1/2 was independent of EGF concentration, validating the specificity of HTRF signals as a measure of the activated ERK1/2 only (Figure 2D). Then, we examined the dose effect of EGFR-mediated ERK1/2 activation in various cell lines: NIH-3T3 

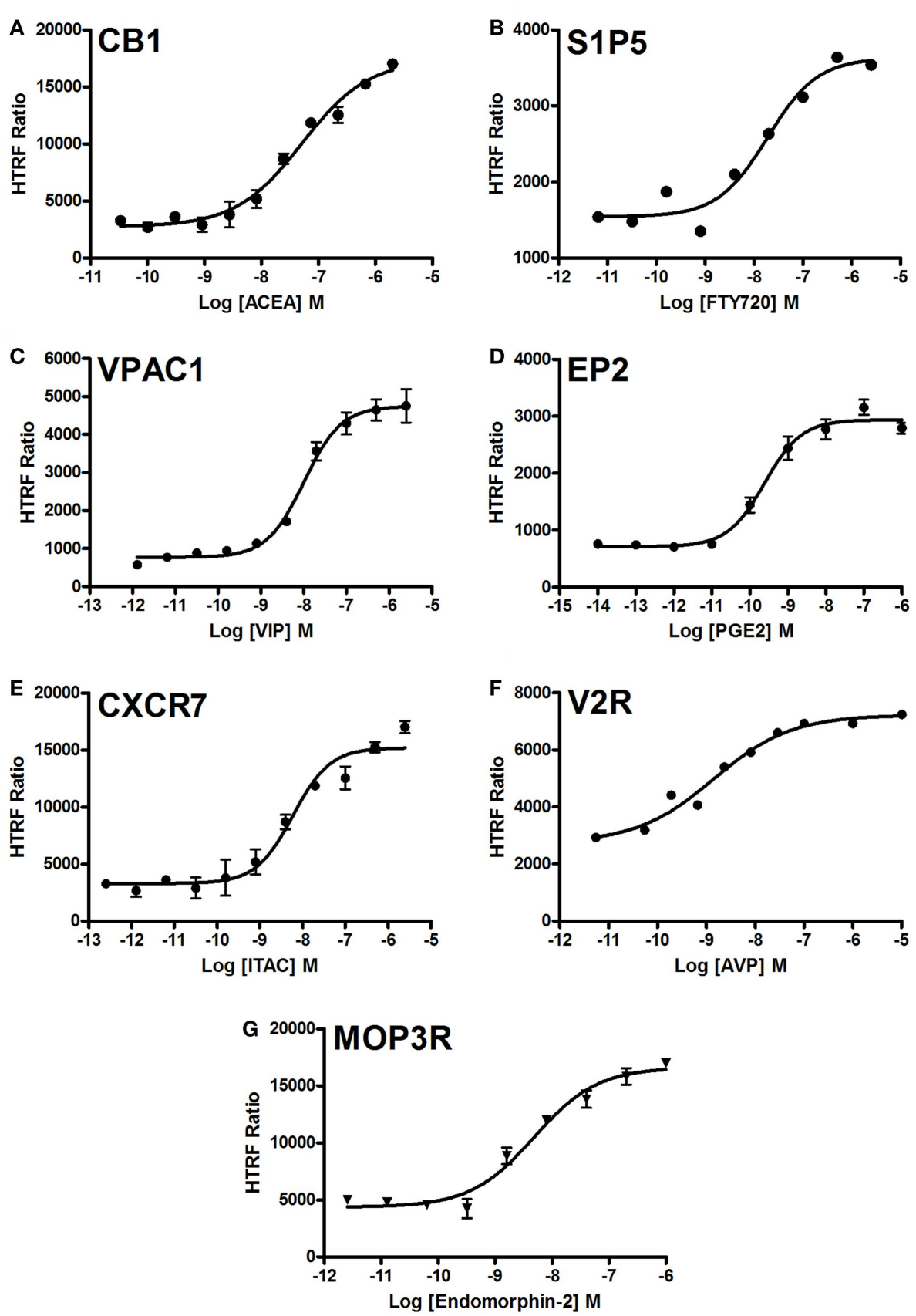

FIGURE 5 | Dose-response analysis of GPCR-mediated

Phospho-ERK1/2 activation. Agonist-induced Phospho-ERK1/2 was assessed using various GPCRs stably expressed in $\mathrm{CHO}$ cells: CB1 (A), S1P5 (B), VPAC1 (C), EP2 (D), CXCR7 (E), V2R (F), and MOP3R (G).
Cells were stimulated for 10 min with increasing concentrations of each GPCR-selective agonist as indicated before HTRF measurements were performed using the one-plate protocol. The figures are representative of three independent experiments performed in single points or duplicate. mouse embryonic fibroblast (Figure 2E), SKOV3 human ovarian carcinoma (Figure 2F), and HEK293 (Figure 2G). For this, we used the one-plate protocol and cells were treated for $5 \mathrm{~min}$ with increasing concentrations of EGF. Such cell lines display large differences in the expression levels of EGFR per cell: 900,000 for A431 and 150,000 for SKOV3 (28), as well as 20,000 for
HEK293 (data not shown). As a result, the HTRF signals reflecting ERK1/2 phosphorylation nicely increased to different extents with the increasing concentrations of EGF, and with the expected potencies ( $\mathrm{pEC}_{50}$ values of $9.22 \pm 0.11$ for A431, $9.46 \pm 0.06$ for $\mathrm{NIH}-3 \mathrm{~T} 3,9.89 \pm 0.10$ for SKOV3, and $9.62 \pm 0.05$ for HEK293) (37-39) regardless of the expression level of EGFR. Together, our 

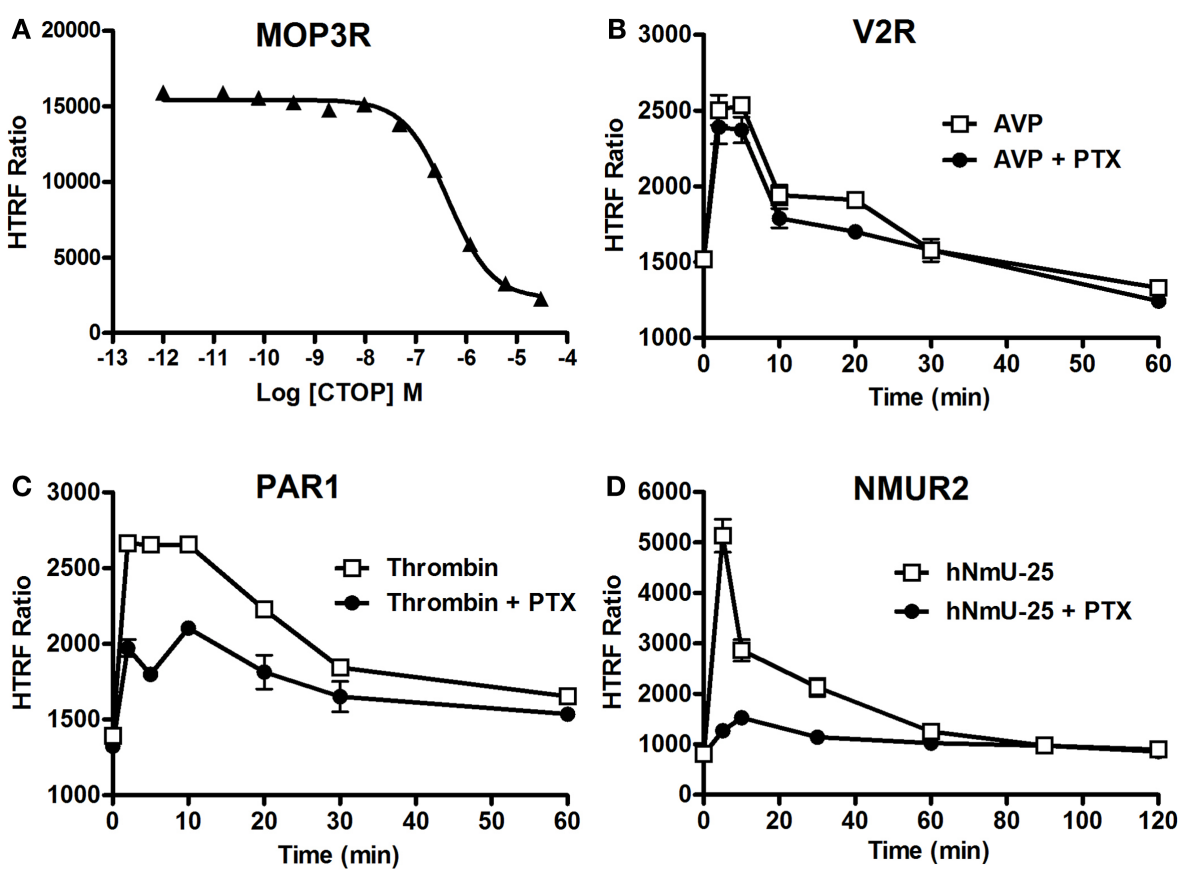

FIGURE 6 | Inhibition of ERK1/2 pathway assessed by the Phospho-ERK assay. $\mathrm{CHO}$ cells stably expressing MOP3R (A) and HEK293 cells transiently expressing V2R (B), PAR1 (C), or NMUR2 (D) were used for the detection of ERK1/2 phosphorylation upon cell stimulation with $2 \mathrm{nM}$ of DAMGO (A),

$100 \mathrm{nM}$ of AVP (B), $1 \mathrm{U} / \mathrm{ml}$ of thrombin (C), or $30 \mathrm{nM}$ of NmU-25 (D) for $5 \mathrm{~min}$,

data clearly demonstrate successful application of the PhosphoERK assay to assess RTK-mediated ERK1/2 signaling in various cell models from human and mouse.

\section{COMPARISON BETWEEN HTRF ${ }^{\circledR}$-BASED AND WESTERN BLOT-BASED ERK1/2 ASSAYS}

As mentioned above, the assessment of ERK1/2 activation by western blot using an antibody recognizing the phosphorylated forms of ERK1/2 represents the widely used method. First, we performed a comparative study on A431 cells. The phosphorylation of ERK1/2 upon stimulation with $100 \mathrm{nM}$ of EGF for $5 \mathrm{~min}$ was measured on the same number of cells comparing the western blot and HTRF ${ }^{\circledR}$-based assay (Phospho-ERK assay) with the one-plate protocol. As shown in Figure 3A, the $\mathrm{HTRF}^{\circledR}$-based assay used to detect the phosphorylated from of ERK1/2 presents a very good signal-to-noise ratio $(\mathrm{S} / \mathrm{N}=18)$. The Phospho-ERK assay was substantially more sensitive than the western blot assay, since $\sim 400$ cells were enough to start detecting specific EGF-induced ERK1/2 phosphorylation using the HTRF ${ }^{\circledR}$-based assay while $\sim 7500-15,000$ cells were needed for the western blot method (Figure 3A). Such a significant difference in the sensitivity between the Phospho-ERK assay and western blot method was also confirmed when the total ERK1/2 levels were quantified in the different cell samples (Figure 3B). Indeed, the normalized quantification of the intensities of western blot bands of the total ERK1/2 clearly indicated that proteins were effectively detected at 1875-3750 cells while 234-468 cells per well were sufficient for using $10^{5}$ cells/well and the two-plate protocol. To assess the inhibition, cells were first pre-treated either with CTOP (A) for 15 min or overnight with $200 \mathrm{ng} / \mathrm{ml}$ of PTX (B-D) before agonist stimulation and HTRF measurements. The data are mean \pm SEM of three independent experiments performed in duplicate.

the specific HTRF signal reflecting the total ERK1/2 (Figure 3C) showing a sensitivity factor of about 10 -fold between the two methods.

\section{USE OF THE PHOSPHO-ERK ASSAY TO MONITOR GPCR-MEDIATED ERK1/2 ACTIVATION}

As stated above, it is now evident that GPCR activation can promote MAP kinase signaling, which has been shown to imply either $G$ protein-dependent and/or G protein-independent activation pathways $(4,40,41)$. Thus, we carried out a series of validation experiments with the Phospho-ERK assay on various GPCRs coupling to different heterotrimeric $\mathrm{G}$ proteins (Gs, Gi/o, Gq). We assessed the kinetics of ERK1/2 phosphorylation mediated by two GPCRs known to induce ERK1/2 activation, vasopressin 2 receptor (V2R) (42), and protease-activated receptor 1 (PAR1) $(43,44)$. The activation of V2R (Figure 4A) and PAR1 (Figure 4B), transiently expressed in HEK293 cells, with $100 \mathrm{nM}$ of AVP and $1 \mathrm{U} / \mathrm{ml}$ of thrombin, respectively, induced a rapid increase in ERK1/2 phosphorylation that showed a sustained stimulation peak at 2-5 min for V2R (Figure 4A) and 2-10 min for PAR1 (Figure 4B). The activation of ERK1/2 was then followed by a slow decline to return back to the basal level after $\sim 30 \mathrm{~min}$ of stimulation. The data obtained with PAR1 are in agreement with the previous observations in astrocytes using the western blot technique (44). These kinetic profiles further demonstrate GPCRs activating the mitogenic signaling pathways known to be mediated through either $\mathrm{G}$ protein-dependent or -independent (i.e., $\beta$-arrestin) pathways (41, 
45). However, many other molecular and cellular factors have been reported to determine the duration and strength of ERK1/2 activation such as cell surface receptor density, expression of scaffolding proteins, and the balance of intracellular kinases and phosphatases $(1,7)$. Next, we extended our analysis to multiple other GPCRs activated for $5 \mathrm{~min}$ with maximal dose $(100 \mathrm{nM})$ of their respective agonists using the one-plate protocol. This resulted in a substantial and specific increase in the HTRF signals compared to mock cells, with similar strength compared to the assay's high control, thereby validating the assay (Figure 4C). To further illustrate the specificity of the GPCR agonist-induced HTRF signals, we tested the effect of cross-stimulation with $100 \mathrm{nM}$ of AVP and angiotensin II (AngII) on the vasopressin V2 (V2R) and angiotensin II (AT1R) receptors transiently expressed in HEK293FT cells. As expected, AVP but not AngII specifically stimulated V2R-mediated ERK1/2 phosphorylation and vice versa AngII but not AVP specifically stimulated AT1Rmediated ERK1/2 phosphorylation (Figure 4D). Neither agonist promoted any ERK1/2 phosphorylation in mock-transfected cells.

\section{DOSE-RESPONSE ANALYSIS OF GPCR-MEDIATED ERK1/2 ACTIVATION}

We examined the dose-dependent effect of the agonists activating various GPCRs stably expressed in CHO cells and using the twoplate protocol (Figure 5). Stimulation of cells for $10 \mathrm{~min}$ with the GPCR-selective agonists resulted in significant dose-dependent increases in the HTRF signals to different extents. The doseresponse curves exhibited the expected potencies of the agonistreceptor pairs, which are close to the nanomolar range. These data clearly demonstrate a successful application of the PhosphoERK assay to assess the phosphorylation and activation of ERK1/2 mediated by GPCR activation regardless of the receptor's $G$ protein coupling profile.

\section{USE OF THE PHOSPHO-ERK ASSAY TO MONITOR INHIBITION OF RECEPTOR-MEDIATED ERK1/2 SIGNALING}

We studied the applicability of the Phospho-ERK assay for investigating inhibitors of cell surface receptors with respect to ERK1/2. For GPCRs, we used $\mu$-opioid receptor 3 (MOP3R) stably expressed in $\mathrm{CHO}$ cells as a model, as this receptor has been shown to activate ERK1/2 (46). These cells were treated with the somatostatin peptide analog (D-Phe-Cys-Tyr-D-Trp-Orn-ThrPen-Thr-NH2; CTOP), which has been described as a selective antagonist of $\mu$-opioid receptors (47). As shown in Figure 6A, pre-treatment of cells for $15 \mathrm{~min}$ with increasing concentrations of CTOP nicely inhibited the DAMGO-induced HTRF signal, indicating the specific inhibition of ERK1/2 activation induced by MOP3R. For EGFR, both the reversible and ATP-competitive EGFR-selective inhibitor, Erlotinib (48) and the specific inhibitory anti-EGFR monoclonal antibody, Cetuximab (49), nicely inhibited the EGF-induced HTRF signal in a dose-dependent manner with the expected potencies $(50,51)$. These data published on the Cisbio website ${ }^{3}$ demonstrate the specificity of EGF-induced HTRF signals, which reflects EGFR activation promoting ERK1/2 phosphorylation.

We then examined the involvement or not of different heterotrimeric G proteins in GPCR-mediated ERK1/2 pathways since

${ }^{3}$ http://www.htrf.com/phospho-erk-thr202tyr204-cellular-assay-kit

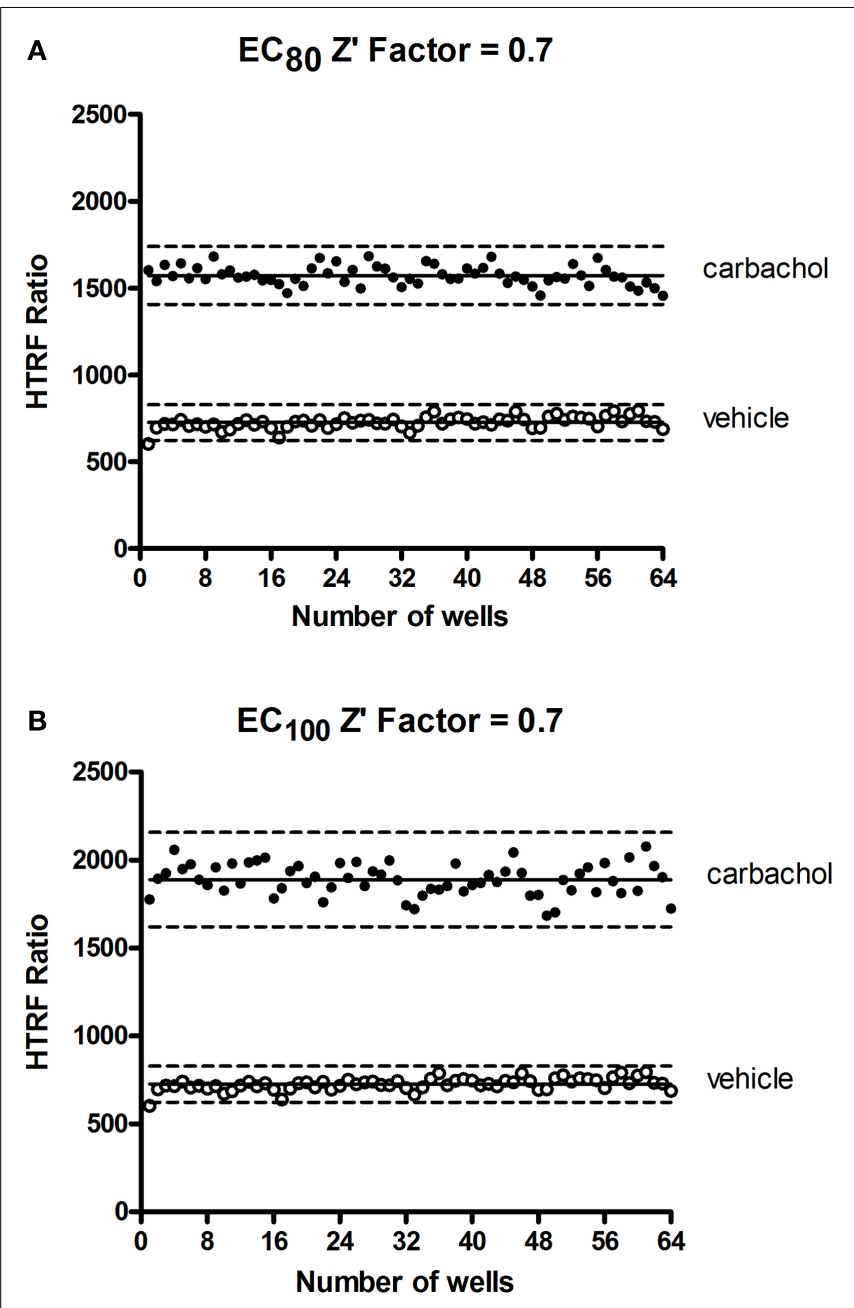

FIGURE $7 \mid Z$ '-factor measurements for the Phospho-ERK assay. $\mathrm{CHO}$ cells stably expressing the muscarinic receptor 1 (M1) were used for the determination of $Z^{\prime}$-factor for the Phospho-ERK1/2 assay using the Phospho-ERK assay one-plate protocol. Cells were stimulated or not with $1.33 \mu \mathrm{M}\left(\mathrm{EC}_{80}\right)$ (A) or $4 \mu \mathrm{M}\left(\mathrm{EC}_{100}\right)$ (B) of carbachol for $15 \mathrm{~min}$ and HTRF signals were measured as described in Section "Materials and Methods." Solid lines show the means of the positive control (carbachol) and negative control (vehicle). Broken lines display three standard deviations from the mean of each data set [Adapted from the CisBio Bioassays website (see text footnote 2) with permission].

GPCRs are known to couple to different classes of heterotrimeric $G$ proteins and to promote ERK1/2 via the activation of $G$ protein-dependent and/or $G$ protein-independent pathways (41, 52). Therefore, we examined the effect of pertussis toxin (PTX) blocking on GPCR-induced ERK1/2 phosphorylation using different GPCRs having different $G$ protein coupling profiles. We tested V2R (mostly Gs) (53), PAR1 (Gi/o, Gq, and G12/13) (54), and neuromedin $\mathrm{U}$ receptor 2 (NMU2R; Gq and $\mathrm{Gi} / \mathrm{o}$ ) reported to activate ERK1/2 (55), as well as MOP3R, which is coupled to PTX-sensitive $\mathrm{Gi} /$ o proteins resulting in inhibition of adenylyl cyclase (56). As shown in Figure 6B, PTX did not affect the kinetics of PhosphoERK1/2 mediated by V2R upon its stimulation with $100 \mathrm{nM}$ of AVP consistent with its PTX-insensitive Gs coupling and the 
previous study demonstrating ERK1/2 being activated by V2R independently of heterotrimeric $\mathrm{G}$ protein signaling (42). In contrast, PTX treatment substantially inhibited the time-dependent ERK1/2 activation mediated by PAR1 following its stimulation with $1 \mathrm{U} / \mathrm{ml}$ of thrombin (Figure $6 \mathrm{C}$ ). This observation is consistent with a role of PTX-sensitive G protein (i.e., Gai/o) (54). However, the partial inhibition by PTX suggests a putative role of another PTX-insensitive G protein (i.e., G $\alpha$ q) and/or G proteinindependent pathway (i.e., $\beta$-arrestins) in PAR1-mediated activation of ERK1/2. For NMU2R, the ERK1/2 activation appears to be primarily mediated by a PTX-sensitive G protein since the signal peak observed at $5 \mathrm{~min}$ post-stimulation with $30 \mathrm{nM}$ of NmU-25 was completely abolished by PTX (Figure 6D). Together, these data clearly demonstrate the successful validation of the Phospho-ERK assay to dissect the signaling pathways and the involvement of $G$ protein-dependent and -independent signaling leading to ERK1/2 activation.

\section{POTENTIAL APPLICATION OF THE PHOSPHO-ERK ASSAY FOR HIGH-THROUGHPUT SCREENING}

In HTS assays, the $Z^{\prime}$-factor is often used as a performance indicator for which an excess of 0.5 indicates high assay performance (57). We determined a $Z^{\prime}$ value for the Phospho-ERK assay using the muscarinic receptor 1 (M1) stably expressed in $\mathrm{CHO}$ cells and stimulated with carbachol. The $Z^{\prime}$ value of 0.7 (Figure 7) demonstrates the potential of Phospho-ERK for screening in a cell-based assay system.

In conclusion, in addition to profiling receptors and their resultant ERK1/2 signaling, the Phospho-ERK assay shows great potential for cell-based HTS. Thus, in combination with the IP-One and cAMP assays $(19,23,24)$, the Phospho-ERK assay completes the innovative panel of $\mathrm{HTRF}^{\circledR}$-based assays dedicated to dissecting and profiling cell surface receptor-mediated signaling (22). This is particularly powerful as it facilitates investigation of the spectrum of ligand-directed and biased signaling, with the activation of ERK1/2 constituting one of the key signaling pathways that has important physiological and pathophysiological implications.

\section{AUTHOR CONTRIBUTIONS}

Mohammed Akli Ayoub initiated, executed most of the experiments on GPCRs and wrote the manuscript; Julien Trebaux and Julie Vallaghe executed the experiments on EGFR; Khaled Al-Hosaini performed the experiment on NMUR2, Fabienne Charrier-Savournin, Arturo Gonzalez Moya, Jean-Philippe Pin, Kevin D. G. Pfleger, and Eric Trinquet initiated and supported the project and Kevin D. G. Pfleger also participated in the writing of the manuscript.

\section{ACKNOWLEDGMENTS}

Work carried out in Kevin D. G. Pfleger's laboratory was funded by ARC Discovery Project Grant DP120101297 and Future Fellowship FT100100271.

\section{REFERENCES}

1. Luttrell LM. Activation and targeting of mitogen-activated protein kinases by G-protein-coupled receptors. Can J Physiol Pharmacol (2002) 80(5):375-82. doi:10.1139/y02-045
2. McKay MM, Morrison DK. Integrating signals from RTKs to ERK/MAPK. Oncogene (2007) 26(22):3113-21. doi:10.1038/sj.onc.1210394

3. Peyssonnaux C, Eychene A. The Raf/MEK/ERK pathway: new concepts of activation. Biol Cell (2001) 93(1-2):53-62. doi:10.1016/S0248-4900(01)01125-X

4. Rozengurt E. Mitogenic signaling pathways induced by $\mathrm{G}$ protein-coupled receptors. J Cell Physiol (2007) 213(3):589-602. doi:10.1002/jcp.21246

5. Rubinfeld H, Seger R. The ERK cascade: a prototype of MAPK signaling. Mol Biotechnol (2005) 31(2):151-74. doi:10.1385/MB:31:2:151

6. Sundaram MV. RTK/Ras/MAPK Signaling. WormBook. (2006). p. 1-19.

7. Murphy LO, Blenis J. MAPK signal specificity: the right place at the right time. Trends Biochem Sci (2006) 31(5):268-75. doi:10.1016/j.tibs.2006.03.009

8. Wortzel I, Seger R. The ERK cascade: distinct functions within various subcellular organelles. Genes Cancer (2011) 2(3):195-209. doi:10.1177/ 1947601911407328

9. Alessi DR, Saito Y, Campbell DG, Cohen P, Sithanandam G, Rapp U, et al. Identification of the sites in MAP kinase kinase-1 phosphorylated by p74raf-1. EMBO $J$ (1994) 13(7):1610-9.

10. Xu S, Robbins D, Frost J, Dang A, Lange-Carter C, Cobb MH. MEKK1 phosphorylates MEK1 and MEK2 but does not cause activation of mitogenactivated protein kinase. Proc Natl Acad Sci U S A (1995) 92(15):6808-12. doi:10.1073/pnas.92.15.6808

11. Chang F, Steelman LS, Lee JT, Shelton JG, Navolanic PM, Blalock WL, et al. Signal transduction mediated by the Ras/Raf/MEK/ERK pathway from cytokine receptors to transcription factors: potential targeting for therapeutic intervention. Leukemia (2003) 17(7):1263-93. doi:10.1038/sj.leu.2402945

12. Friedman A, Perrimon N. High-throughput approaches to dissecting MAPK signaling pathways. Methods (2006) 40(3):262-71. doi:10.1016/j.ymeth.2006. 05.002

13. Spitzer P, Schieb H, Kamrowski-Kruck H, Otto M, Chiasserini D, Parnetti L, et al. Evidence for elevated cerebrospinal fluid ERK1/2 levels in Alzheimer dementia. Int J Alzheimers Dis (2011) 2011:739847. doi:10.4061/2011/739847

14. Lange F, Rateitschak K, Fitzner B, Pohland R, Wolkenhauer O, Jaster R. Studies on mechanisms of interferon-gamma action in pancreatic cancer using a datadriven and model-based approach. Mol Cancer (2011) 10(1):13. doi:10.1186/ 1476-4598-10-13

15. Dalrymple MB, Jaeger WC, Eidne KA, Pfleger KD. Temporal profiling of orexin receptor-arrestin-ubiquitin complexes reveals differences between receptor subtypes. J Biol Chem (2011) 286(19):16726-33. doi:10.1074/jbc.M111.223537

16. Osmond RIW, Sheehan A, Borowicz R, Barnett E, Harvey G, Turner C, et al. GPCR screening via ERK 1/2: a novel platform for screening $G$ protein-coupled receptors. J Biomol Screen (2005) 10(7):730-37. doi:10.1177/1087057105277968

17. Eishingdrelo H, Kongsamut S. Minireview: targeting GPCR activated ERK pathways for drug discovery. Curr Chem Genomics Transl Med (2013) 7:9-15. doi:10.2174/2213988501307010009

18. Xu C, Peter M, Bouquier N, Ollendorff V, Villamil I, Liu J, et al. REV, a BRET-based sensor of ERK activity. Front Endocrinol (Lausanne) (2013) 4:95. doi:10.3389/fendo.2013.00095

19. Degorce F, Card A, Soh S, Trinquet E, Knapik GP, Xie B. HTRF: a technology tailored for drug discovery - a review of theoretical aspects and recent applications. Curr Chem Genomics (2009) 3:22-32. doi:10.2174/1875397300903010022

20. Mathis G. HTRF(R) technology. J Biomol Screen (1999) 4(6):309-14. doi:10. 1177/108705719900400605

21. Armstrong SP, Seeber RM, Ayoub MA, Feldman BJ, Pfleger KD. Characterization of three vasopressin receptor 2 variants: an apparent polymorphism (V266A) and two loss-of-function mutations (R181C and M311V). PLoS One (2013) 8(6):e65885. doi:10.1371/journal.pone.0065885

22. Norskov-Lauritsen L, Thomsen AR, Brauner-Osborne H. G protein-coupled receptor signaling analysis using homogenous time-resolved Forster resonance energy transfer (HTRF(R)) technology. Int J Mol Sci (2014) 15(2):2554-72. doi:10.3390/ijms15022554

23. Trinquet E, Bouhelal R, Dietz M. Monitoring Gq-coupled receptor response through inositol phosphate quantification with the IP-one assay. Expert Opin Drug Discov (2011) 6(10):981-94. doi:10.1517/17460441.2011.608658

24. Trinquet E, Fink M, Bazin H, Grillet F, Maurin F, Bourrier E, et al. D-myo-inositol 1-phosphate as a surrogate of D-myo-inositol 1,4,5-tris phosphate to monitor $\mathrm{G}$ protein-coupled receptor activation. Anal Biochem (2006) 358(1):126-35. doi:10.1016/j.ab.2006.08.002

25. Jia Y, Quinn CM, Gagnon AI, Talanian R. Homogeneous time-resolved fluorescence and its applications for kinase assays in drug discovery. Anal Biochem (2006) 356(2):273-81. doi:10.1016/j.ab.2006.05.006 
26. Albizu L, Cottet M, Kralikova M, Stoev S, Seyer R, Brabet I, et al. Time-resolved FRET between GPCR ligands reveals oligomers in native tissues. Nat Chem Biol (2010) 6(8):587-94. doi:10.1038/nchembio.396

27. Maurel D, Comps-Agrar L, Brock C, Rives ML, Bourrier E, Ayoub MA, et al. Cellsurface protein-protein interaction analysis with time-resolved FRET and snaptag technologies: application to GPCR oligomerization. Nat Methods (2008) 5(6):561-7. doi: 10.1038/nmeth.1213

28. Gaborit N, Larbouret C, Vallaghe J, Peyrusson F, Bascoul-Mollevi C, Crapez E, et al. Time-resolved fluorescence resonance energy transfer (TR-FRET) to analyze the disruption of EGFR/HER2 dimers: a new method to evaluate the efficiency of targeted therapy using monoclonal antibodies. J Biol Chem (2011) 286(13):11337-45. doi:10.1074/jbc.M111.223503

29. Ayoub MA, Trinquet E, Pfleger KD, Pin JP. Differential association modes of the thrombin receptor PAR1 with Galphail, Galpha12, and beta-arrestin 1. FASEB $J$ (2010) 24(9):3522-35. doi:10.1096/fj.10-154997

30. Loison S, Cottet M, Orcel H, Adihou H, Rahmeh R, Lamarque L, et al. Selective fluorescent nonpeptidic antagonists for vasopressin V(2) GPCR: application to ligand screening and oligomerization assays. J Med Chem (2012) 55(20):8588-602. doi:10.1021/jm3006146

31. Vauthier V, Derviaux C, Douayry N, Roux T, Trinquet E, Jockers R, et al. Design and validation of a homogeneous time-resolved fluorescence-based leptin receptor binding assay. Anal Biochem (2013) 436(1):1-9. doi:10.1016/j.ab.2012.12.013

32. Dodeller F, Gottar M, Huesken D, Iourgenko V, Cenni B. The lysosomal transmembrane protein $9 \mathrm{~B}$ regulates the activity of inflammatory signaling pathways. J Biol Chem (2008) 283(31):21487-94. doi:10.1074/jbc.M801908200

33. Lopez-Crapez E, Malinge JM, Gatchitch F, Casano L, Langlois T, Pugniere $\mathrm{M}$, et al. A homogeneous resonance energy transfer-based assay to monitor MutS/DNA interactions. Anal Biochem (2008) 383(2):301-6. doi:10.1016/j.ab. 2008.09.004

34. Balaji K, Mooser C, Janson CM, Bliss JM, Hojjat H, Colicelli J. RIN1 orchestrates the activation of RAB5 GTPases and ABL tyrosine kinases to determine the fate of EGFR. J Cell Sci (2012) 125(Pt 23):5887-96. doi:10.1242/jcs. 113688

35. Casar B, Arozarena I, Sanz-Moreno V, Pinto A, Agudo-Ibanez L, Marais R, et al. Ras subcellular localization defines extracellular signal-regulated kinase 1 and 2 substrate specificity through distinct utilization of scaffold proteins. Mol Cell Biol (2009) 29(5):1338-53. doi:10.1128/MCB.01359-08

36. Taub N, Teis D, Ebner HL, Hess MW, Huber LA. Late endosomal traffic of the epidermal growth factor receptor ensures spatial and temporal fidelity of mitogenactivated protein kinase signaling. Mol Biol Cell (2007) 18(12):4698-710. doi:10.1091/mbc.E07-02-0098

37. Balestreire EM, Apodaca G. Apical epidermal growth factor receptor signaling: regulation of stretch-dependent exocytosis in bladder umbrella cells. Mol Biol Cell (2007) 18(4):1312-23. doi:10.1091/mbc.E06-09-0842

38. Neelam B, Richter A, Chamberlin SG, Puddicombe SM, Wood L, Murray $\mathrm{MB}$, et al. Structure-function studies of ligand-induced epidermal growth factor receptor dimerization. Biochemistry (1998) 37(14):4884-91. doi:10.1021/ bi972548x

39. Schiffer HH, Reding EC, Fuhs SR, Lu Q, Piu F, Wong S, et al. Pharmacology and signaling properties of epidermal growth factor receptor isoforms studied by bioluminescence resonance energy transfer. Mol Pharmacol (2007) 71(2):508-18. doi:10.1124/mol.106.027656

40. Lefkowitz RJ, Shenoy SK. Transduction of receptor signals by beta-arrestins. Science (2005) 308(5721):512-7. doi:10.1126/science.1109237

41. Shenoy SK, Drake MT, Nelson CD, Houtz DA, Xiao K, Madabushi S, et al. Beta-arrestin-dependent, $G$ protein-independent ERK1/2 activation by the beta2 adrenergic receptor. J Biol Chem (2006) 281(2):1261-73. doi:10.1074/jbc. M506576200

42. Charest PG, Bouvier M. Palmitoylation of the V2 vasopressin receptor carboxyl tail enhances beta-arrestin recruitment leading to efficient receptor endocytosis and ERK1/2 activation. J Biol Chem (2003) 278(42):41541-51. doi:10.1074/jbc.M306589200

43. McCoy KL, Gyoneva S, Vellano CP, Smrcka AV, Traynelis SF, Hepler JR. Proteaseactivated receptor 1 (PAR1) coupling to $G(q / 11)$ but not to $G(i / o)$ or $G(12 / 13)$ is mediated by discrete amino acids within the receptor second intracellular loop. Cell Signal (2012) 24(6):1351-60. doi:10.1016/j.cellsig.2012.01.011

44. Wang H, Ubl JJ, Stricker R, Reiser G. Thrombin (PAR-1)-induced proliferation in astrocytes via MAPK involves multiple signaling pathways. Am J Physiol Cell Physiol (2002) 283(5):C1351-64. doi:10.1152/ajpcell.00001.2002
45. Ahn S, Shenoy SK, Wei H, Lefkowitz RJ. Differential kinetic and spatial patterns of beta-arrestin and $G$ protein-mediated ERK activation by the angiotensin II receptor. J Biol Chem (2004) 279(34):35518-25. doi:10.1074/jbc. M405878200

46. Belcheva MM, Vogel Z, Ignatova E, Avidor-Reiss T, Zippel R, Levy R, et al. Opioid modulation of extracellular signal-regulated protein kinase activity is ras-dependent and involves Gbetagamma subunits. J Neurochem (1998) 70(2):635-45. doi:10.1046/j.1471-4159.1998.70020635.x

47. Chieng B, Connor M, Christie MJ. The mu-opioid receptor antagonist D-PheCys-Tyr-D-Trp-Orn-Thr-Pen-Thr-NH2 (CTOP) [but not D-Phe-Cys-Tyr-DTrp-Arg-Thr-Pen-Thr-NH2 (CTAP)] produces a nonopioid receptor-mediated increase in $\mathrm{K}+$ conductance of rat locus ceruleus neurons. Mol Pharmacol (1996) 50(3):650-5.

48. Feld R, Sridhar SS, Shepherd FA, Mackay JA, Evans WK. Use of the epidermal growth factor receptor inhibitors gefitinib and erlotinib in the treatment of nonsmall cell lung cancer: a systematic review. J Thorac Oncol (2006) 1(4):367-76. doi:10.1097/01243894-200605000-00018

49. Graham J, Muhsin M, Kirkpatrick P. Cetuximab. Nat Rev Drug Discov (2004) 3(7):549-50. doi:10.1038/nrd1445

50. Doody JF, Wang Y, Patel SN, Joynes C, Lee SP, Gerlak J, et al. Inhibitory activity of cetuximab on epidermal growth factor receptor mutations in non small cell lung cancers. Mol Cancer Ther (2007) 6(10):2642-51. doi:10.1158/1535-7163. MCT-06-0506

51. Feng FY, Lopez CA, Normolle DP, Varambally S, Li X, Chun PY, et al. Effect of epidermal growth factor receptor inhibitor class in the treatment of head and neck cancer with concurrent radiochemotherapy in vivo. Clin Cancer Res (2007) 13(8):2512-8. doi:10.1158/1078-0432.CCR-062582

52. Luttrell LM, Lefkowitz RJ. The role of beta-arrestins in the termination and transduction of G-protein-coupled receptor signals. J Cell Sci (2002) 115(Pt 3):455-65.

53. Birnbaumer M, Seibold A, Gilbert S, Ishido M, Barberis C, Antaramian A, et al. Molecular cloning of the receptor for human antidiuretic hormone. Nature (1992) 357(6376):333-5. doi:10.1038/357333a0

54. Trejo J. Protease-activated receptors: new concepts in regulation of G proteincoupled receptor signaling and trafficking. J Pharmacol Exp Ther (2003) 307(2):437-42. doi:10.1124/jpet.103.052100

55. Brighton PJ, Szekeres PG, Wise A, Willars GB. Signaling and ligand binding by recombinant neuromedin $U$ receptors: evidence for dual coupling to Galphaq/11 and Galphai and an irreversible ligand-receptor interaction. Mol Pharmacol (2004) 66(6):1544-56. doi:10.1124/mol.104.002337

56. Burford NT, Wang D, Sadee W. G-protein coupling of mu-opioid receptors (OP3): elevated basal signalling activity. Biochem J (2000) 348(Pt 3):531-7. doi:10.1042/0264-6021:3480531

57. Zhang JH, Chung TD, Oldenburg KR. A simple statistical parameter for use in evaluation and validation of high throughput screening assays. J Biomol Screen (1999) 4(2):67-73. doi:10.1177/108705719900400206

Conflict of Interest Statement: Julien Trebaux, Julie Vallaghe, Fabienne CharrierSavournin, Arturo Gonzalez Moya, and Eric Trinquet are all employees of CisBio Bioassays, which markets the HTRF Phospho-ERK kit (Catalogue number 64ERKPEG). The other co-authors report no conflicts of interest.

Received: 13 April 2014; accepted: 04 June 2014; published online: 23 June 2014. Citation: Ayoub MA, Trebaux J, Vallaghe J, Charrier-Savournin F, Al-Hosaini K, Gonzalez Moya A, Pin J-P, Pfleger KDG and Trinquet E (2014) Homogeneous time-resolved fluorescence-based assay to monitor extracellular signal-regulated kinase signaling in a high-throughput format. Front. Endocrinol. 5:94. doi: 10.3389/fendo.2014.00094 This article was submitted to Molecular and Structural Endocrinology, a section of the journal Frontiers in Endocrinology.

Copyright (C) 2014 Ayoub, Trebaux, Vallaghe, Charrier-Savournin, Al-Hosaini, Gonzalez Moya, Pin, Pfleger and Trinquet. This is an open-access article distributed under the terms of the Creative Commons Attribution License (CC BY). The use, distribution or reproduction in other forums is permitted, provided the original author (s) or licensor are credited and that the original publication in this journal is cited, in accordance with accepted academic practice. No use, distribution or reproduction is permitted which does not comply with these terms. 